\title{
The Effect of Mobile App Interventions on Influencing Healthy Maternal Behavior and Improving Perinatal Health Outcomes: Systematic Review
}

Lisa M Daly ${ }^{1}$, BA, MPH; Dell Horey ${ }^{2}$, BAppSciChem, MMedSc, PhD; Philippa F Middleton ${ }^{3}$, BSc, MPH, PHAA, $\mathrm{PhD}$; Frances M Boyle ${ }^{1}$, BA, PhD; Vicki Flenady ${ }^{1}$, GDipClinEpiBiostats, MMSc, PhD

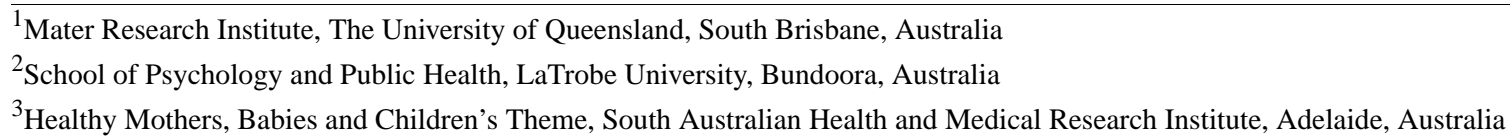

\section{Corresponding Author:}

Lisa M Daly, BA, MPH

Mater Research Institute

The University of Queensland

Level 3, Aubigny Place

South Brisbane, 4101

Australia

Phone: 61731635330

Fax: 61731632550

Email: lisa.daly@uq.edu.au

\section{Abstract}

Background: Perinatal morbidity and mortality are significant public health issues with an enduring impact on the health and well-being of women and their families. Millions of pregnant women now download and use mobile applications to access, store, and share health information. However, little is known about the consequences. An investigation of their impact on perinatal health outcomes is particularly topical.

Objective: To determine the effects of mobile app interventions during pregnancy on influencing healthy maternal behavior and improving perinatal health outcomes.

Methods: Searches of PubMed, Embase, the Cochrane Library, CINAHL, WHO Global Health Library, POPLINE, and CABI Global Health were conducted with no date or language restrictions. Randomized and non-randomized studies were included if they reported perinatal health outcomes of interventions targeting pregnant women, using mobile apps compared with other communication modalities or with standard care. The primary outcome measure was the change in maternal behaviors (as defined by trial authors), by intervention goals. Two reviewers independently extracted data using standardized forms.

Results: Four randomized controlled trials (RCTs) involving 456 participants were included. All studies targeted participants in early pregnancy; however, wide variation was evident in participant characteristics, intervention, and study outcomes measures. Three trials were based in hospital settings, comparing women using mobile apps with routine antenatal care. One community-based trial gave all participants a device to promote physical activity; the intervention arm was also given a mobile app. All studies reported data for the primary outcome measure, describing some benefit from the intervention compared with controls. However, few statistically significant primary or secondary outcomes were reported. Due to insufficient data, the planned meta-analysis and subgroup analyses were not performed.

Conclusions: Due to limited numbers, heterogeneity of interventions, comparators, and outcome measures, no firm conclusions can be drawn on the effects of mobile application interventions during pregnancy on maternal knowledge, behavior change, and perinatal health outcomes. As millions of women utilize mobile apps during pregnancy, rigorous studies are essential for health care and maternity care providers to optimally design, implement, and evaluate interventions.

(JMIR Mhealth Uhealth 2018;6(8):e10012) doi: $\underline{10.2196 / 10012}$

\section{KEYWORDS}

apps; pregnancy; perinatal; maternal; infant; mobile; systematic review; behavior change; intervention 


\section{Introduction}

Adoption, practice, and maintenance of healthy behaviors during pregnancy can potentially improve maternal and child health. Adverse perinatal health outcomes such as emergency cesarean section, preterm birth, low birthweight, and stillbirth [1] are associated with maternal risk factors that may be modifiable through changes in maternal behavior [2-4]. During pregnancy and in preparation for motherhood, many women seek information and try to adopt a healthy lifestyle [5]. Pregnant women are increasingly using digital resources such as mobile apps-computer programs designed to run on mobile devices such as mobile phones and tablet computers-to access information, monitor fetal development, track individual health indicators, and provide reassurance [6-10]. Collectively, pregnancy apps have been downloaded hundreds of millions of times and are an integral source of information for many pregnant women [11]. Pregnant women may feel heightened support for informed decision-making and a sense of control by using a familiar device to access, store, and share information [9].

In 2017, over 325,000 health and fitness and medical apps were available [12]; apps directed at pregnancy constitute a major genre [13]. These apps can include health information, motivational messages, monitoring, and behavior change tools. The content of apps can be tailored by demographics such as gestational age, maternal age, language or risk factors. App developers may employ methods to engage users, such as "push communication," including notifications designed to encourage users to follow a prompt (eg, read, listen, view content or perform an activity). Pregnancy apps may also link to a device such as a camera, glucometer, fitness activity tracker, Kegel "exerciser," fetal heartbeat "listener," or other monitoring equipment. Some devices associated with an app are marketed directly to consumers and avoid regulatory scrutiny, while a woman's health care provider may provide other devices as part of clinical care.

From an institutional perspective, health systems and maternity care facilities are investigating whether and how to integrate digital patient support modalities into care and are seeking evidence to support decision making. It has been hypothesized that mobile apps may improve perinatal outcomes by encouraging access to health information, modifying demand for services, and enabling provision of targeted care [14]. This systematic review aims to determine the effects of mobile app interventions during pregnancy on influencing healthy maternal behavior and improving perinatal health outcomes, compared to interventions using other communication modalities or standard care.

\section{Methods}

\section{Criteria for Considering Studies for this Review}

\section{Study Design}

All randomized controlled trials (RCTs) and non-randomized studies including controlled before-after studies, interrupted time-series studies, and prospective comparative cohort studies were considered for inclusion. Case-control studies and cross-sectional studies were excluded due to their retrospective design. Crossover trials were also excluded as they are considered most suitable for temporary effects and chronic conditions [15]. Women at any stage of pregnancy or labor were considered for participation.

\section{Interventions}

Studies assessing the effects of mobile app-based interventions designed to influence maternal knowledge or behavior during pregnancy were considered for inclusion if they provided general information for pregnant women or focused on a specific maternal risk factor or perinatal outcome. There was no restriction on who sponsored the intervention or type of setting.

Studies were excluded if the intervention (1) did not utilize a mobile app, (2) used a mobile phone solely for telephone conversations or SMS (short message service) text messaging, (3) did not report on maternal or infant health outcomes, (4) did not target pregnant women (focus on clinicians, partners), and (5) focused on physical effects of mobile phone usage (such as radiation) during pregnancy.

\section{Comparators}

The following comparisons were planned:

1. Mobile health apps versus paper-based or SMS text messaging-based communications.

2. Mobile health apps versus interpersonal communication modes (ie, face-to-face or telephone conversation).

3. Mobile health apps versus standard care or no specified intervention.

\section{Outcome Measures}

The primary outcome measure was a change in maternal behaviors (as defined by trial authors), by intervention goals. Secondary outcomes addressed maternal and infant health outcomes, maternal experience with the intervention, and health service utilization measures (Table 1).

\section{Search Methods for Identification of Studies}

\section{Sources}

Systematic searches were performed using seven electronic bibliographic databases: PubMed, Embase, The Cochrane Library, CINAHL, World Health Organization Global Health Library, POPLINE, and CABI Global Health. Handsearching of journals and conference proceedings from the reference lists of retrieved studies were also conducted. No language or date restrictions were applied. Abstracts and full-length articles were obtained for each citation, where available.

\section{Search Strategy}

The specific search strategies were developed by the primary author (LMD) and an experienced clinical research librarian, with input from all authors. Electronic searches using subject headings and all fields for keywords were conducted to avoid missing non-indexed concepts. Search terms and returns by the database and handsearching are presented in Multimedia Appendix 1. Articles published in non-peer reviewed publications were excluded, as per the review protocol. 
Remaining citations and abstracts were uploaded to the Web-based software platform Covidence [16]. Throughout the review process, authors were not blinded to journal titles, study authors or institutions. If it was unclear whether studies met inclusion criteria, study authors were contacted up to two times by email to request further information.

\section{Study Selection}

Abstracts of articles retrieved through the search strategy were independently screened by 2 review authors to determine if inclusion and exclusion criteria were met. A third author addressed any concerns about inclusion. If necessary, additional information was sought from study authors to resolve eligibility queries. For selected studies, full-text articles were obtained and read by 2 authors to confirm that they met inclusion criteria.

\section{Bias Assessment}

Studies were assessed for quality by 2 reviewers independently (LMD, VF), according to the guidelines in the Cochrane Handbook for Systematic Reviews of Interventions [17], by 6 domains: (1) selection bias, (2) performance bias, (3) detection bias, (4) attrition bias, (5) reporting bias, and (6) any other possible bias. All included studies were assessed on the risk of bias, likely magnitude, and potential impact on findings.

\section{Data Collection and Analysis}

\section{Data Extraction and Management}

Once the studies were selected, using standardized forms, 2 reviewers (LMD, VF) independently extracted data including study objective, study design, inclusion and exclusion criteria, data sources, study period, methodology, sample size, intervention details and effects, and outcomes. Due to the complexity of the interventions found, a post-hoc decision was taken to collect data on the interventions based on the Template for Intervention Description and Replication (TIDieR) checklist $[18,19]$.

\section{Synthesis of Results}

As described in the review protocol [20], we set out to synthesize data and present measures of treatment effects including summary risk ratios for dichotomous outcomes and mean difference for continuous data and subgroup analysis. Due to the considerable heterogeneity of participant characteristics, intervention features, and reported outcomes, it was decided that meta-analysis could not be performed, and results were summarized in a narrative synthesis.

Table 1. Primary and secondary outcome measures.

\begin{tabular}{|c|c|}
\hline Outcome & Outcome characteristics \\
\hline \multicolumn{2}{|c|}{ Primary outcomes } \\
\hline Maternal & - Change in maternal behaviors (as defined by trial authors), by intervention goals \\
\hline \multicolumn{2}{|c|}{ Secondary outcomes } \\
\hline Maternal & 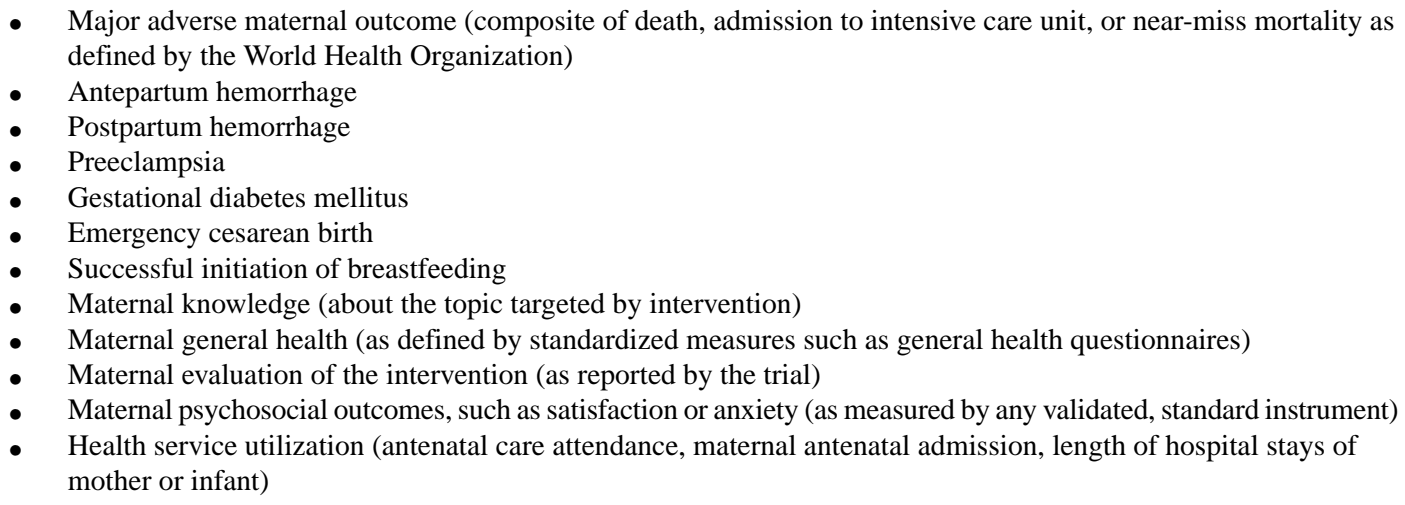 \\
\hline Infant & $\begin{array}{ll}\text { - } & \text { Stillbirth } \\
\text { - } & \text { Neonatal death } \\
\text { - } & \text { Small for gestational age } \\
\text { - } & \text { Large for gestational age } \\
\text { - } & \text { Preterm birth }(<32 \text { weeks' gestation) } \\
\text { - } & \text { Gestational age at birth } \\
\text { - } & \text { Cesarean section } \\
\text { - } & \text { Major neonatal morbidities (as defined by trial authors) }\end{array}$ \\
\hline
\end{tabular}




\section{Results}

\section{Description of Studies}

\section{Included Studies}

The search strategy for this review has been consolidated into a Preferred Reporting Items for Systematic Reviews and Meta-Analysis (PRISMA) diagram (Figure 1), summarizing inclusion and exclusion of studies [21]. For database screening, one author (LMD) searched the databases on 15-16 February 2017 , with a yield of 5,089 articles. After initial screening to remove duplicates and articles from non-peer reviewed journals, the titles and abstracts of 2,241 articles were reviewed by 2 authors independently (among LMD, VF, DH, PFM, and FMB). Title and abstract screening of 1,091 additional articles identified through handsearching was performed by 2 reviewers (LMD and VF); however, no additional studies were identified. Full-text screening of 69 articles was performed by 2 review authors (among LMD, VF, PFM, and DH). At all stages, disagreements between authors were resolved by consultation with a third reviewer. Reasons were recorded for excluding studies (Multimedia Appendix 2). Several articles had multiple reasons for exclusion, although each was allocated to a single category. A total of 4 trials met the inclusion criteria.

The characteristics of included studies are presented in Table 2. Though not specified as a requirement for inclusion, all studies that met inclusion criteria used RCT designs and involved pregnant women in high-income countries. Three trials were based in hospital settings, comparing women using mobile apps with standard antenatal care. One community-based trial gave all participants a device to promote physical activity; participants in the intervention arm were also given a mobile app.

\section{Bias Assessment of Included Studies}

Objective assessments and validated data collection tools were employed in all included studies. Studies performed generally well regarding the risk of bias in random sequence generation; 3 studies were low risk and 1 study was unclear, as it was not described. High risk of performance bias was shared across all studies. Due to the nature of mobile app interventions, blinding participants is difficult, and did not occur in any of the included studies. Blinding health care providers can also be difficult and occurred in only 1 study. Most studies had a low risk of attrition bias, with low rates of withdrawal, drop-out or loss to follow-up. Reporting biases were also low, with all studies reporting results for their respective primary outcomes. The overall risk assessment is presented in Multimedia Appendix 3.

\section{Description of Participants}

Overall, 456 pregnant women participated in the 4 included trials, with 180 women categorized as low risk in 2 trials and 276 as moderate risk in 2 trials. Of these, 1 trial included pregnant women with asthma and another recruited pregnant women classified as overweight or obese. All trials recruited women prior to 20 weeks gestation. Table 3 shows the participant characteristics reported by each study.

\section{Description of Interventions}

All interventions used mobile apps specifically designed for the study, rather than apps available through commercial "app stores." None of the included studies reported if modification of the intervention occurred during the trial or described a cost-benefit analysis or compared cost of the app to other communication modalities. To motivate users to engage with the content, 2 studies developed apps utilizing "push" communication strategies. These same interventions also included a device available through a "plug-in" $[23,25]$. Three studies allowed users to record and track personal data within the app and provided individualized information [22,23,25]. None of the studies reported that their apps included shared participant "chat" spaces. Intervention features are described using the TIDieR checklist [18,19] presented in Table 4. Additional information about intervention characteristics-including user experience, content, patient-provider communication, functionality, and data tracking-was also collected by one reviewer (LMD) using a customized form (Multimedia Appendix 4).

\section{Effects of Interventions}

The included trials reported different maternal and infant health outcomes such that meta-analysis or subgroup analysis was not possible.

\section{Primary Outcomes}

The primary outcome of interest was a change in maternal behaviors (as defined by trial authors), by intervention goals. All studies reported some type of behavior change and better results for the intervention group than controls for their respective primary outcomes (Table 5). Inventories and data collection tools used in the included studies are listed in Multimedia Appendix 5. The Ainscough et al study [22] concluded that a significantly higher proportion of the intervention group had transitioned to a "maintenance stage" of healthy lifestyle behaviors by 28 weeks' gestation, compared to the control group $(52.8 \%$ versus $32.7 \%, P=.004)$. The primary outcome measure for the Choi et al study [23] of physical activity was weekly mean steps, and intervention participants had a greater increase in daily steps at 12 weeks with 1096 (SD 1898) steps, compared with 259 (SD 1604) steps among control participants $(P=.13)$. The change between groups reported across the 12-week study period was not statistically significant $(P=.38)$. The Ledford et al study [24] found that by 32 weeks' gestation, participants using a mobile app recorded information more frequently than the control group, and that they had developed greater "patient activation" than the control group ( $F[1127]=4.99, P \geq .05, \mathrm{n}^{2}=.04$, marginal mean of 79.88 versus 74.81). The Zairina et al study [25] reported that the intervention group had a higher proportion of participants with well-controlled asthma than the control group ( $82 \%$ versus $58 \%$, $P=.03$ ) at 6 months from baseline. 
Figure 1. Preferred Reporting Items for Systematic Reviews and Meta-Analysis diagram of included and excluded studies.

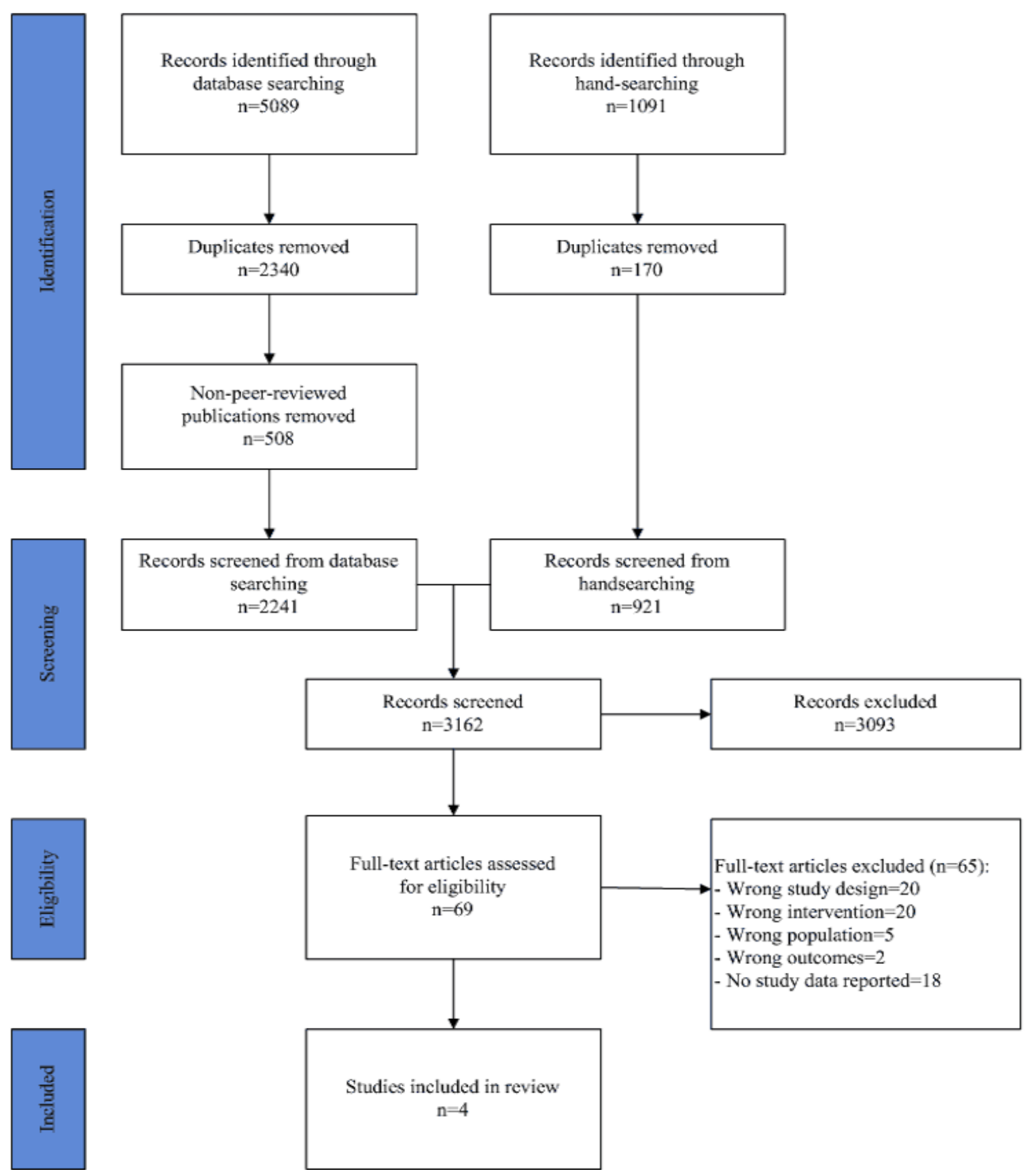


Table 2. The characteristics of included studies.

\begin{tabular}{|c|c|c|c|c|}
\hline Study characteristics & Ainscough et al [22] & Choi et al [23] & Ledford et al [24] & Zairina et al [25] \\
\hline Country & Ireland & United States & United States & Australia \\
\hline Year & 2016 & 2016 & 2016 & 2016 \\
\hline Design & Randomized controlled trial & Randomized controlled trial & Randomized controlled trial & Randomized controlled trial \\
\hline Aim & $\begin{array}{l}\text { To investigate the influence } \\
\text { of a mobile phone app-sup- } \\
\text { ported antenatal healthy } \\
\text { lifestyle intervention on the } \\
\text { behavioral stage of change } \\
\text { among overweight and } \\
\text { obese pregnant women }\end{array}$ & $\begin{array}{l}\text { To examine the feasibility } \\
\text { of subject recruitment, ran- } \\
\text { domization, intervention, } \\
\text { and efficacy of an mHealth } \\
\text { physical activity program } \\
\text { for physically inactive preg- } \\
\text { nant women }\end{array}$ & $\begin{array}{l}\text { To compare the effective- } \\
\text { ness of a mobile application } \\
\text { with a spiral-notebook guide } \\
\text { in prenatal care }\end{array}$ & $\begin{array}{l}\text { To evaluate the efficacy of } \\
\text { a telehealth program support- } \\
\text { ed by a handheld respiratory } \\
\text { device in improving asthma } \\
\text { control during pregnancy }\end{array}$ \\
\hline Participants (risk category) & $\begin{array}{l}204 \text { pregnant women with } \\
\text { body mass index } \geq 25 \text { and } \\
<40 \mathrm{~kg} / \mathrm{m}^{2} \text { (Moderate) }\end{array}$ & $\begin{array}{l}30 \text { pregnant women with a } \\
\text { sedentary lifestyle and intent } \\
\text { to be physically active } \\
\text { (Low) }\end{array}$ & $\begin{array}{l}150 \text { low-risk obstetrics par- } \\
\text { ticipants following standard } \\
\text { care pathway (Low) }\end{array}$ & $\begin{array}{l}72 \text { pregnant women with } \\
\text { asthma (Moderate) }\end{array}$ \\
\hline Control group (n) & $\begin{array}{l}\text { Standard care: no consistent } \\
\text { diet or lifestyle advice of- } \\
\text { fered (98) }\end{array}$ & $\begin{array}{l}\text { Recommendations for gesta- } \\
\text { tional weight gain and safety } \\
\text { instruction for promoting } \\
\text { physical activity during } \\
\text { pregnancy, and an ac- } \\
\text { celerometer (15) }\end{array}$ & $\begin{array}{l}\text { Standard care: a spiral note- } \\
\text { book designed to educate } \\
\text { participants about pregnancy } \\
\text { and enable recording of } \\
\text { pregnancy experiences ( } 78 \text { ) }\end{array}$ & $\begin{array}{l}\text { Standard care through a par- } \\
\text { ticipant information } \\
\text { brochure (36) }\end{array}$ \\
\hline Intervention group (n) & $\begin{array}{l}\text { A "healthy lifestyle pack- } \\
\text { age" of individualized nutri- } \\
\text { tion counseling and exercise } \\
\text { advice, supported by a mo- } \\
\text { bile phone app (106) }\end{array}$ & $\begin{array}{l}\text { The same information and } \\
\text { an accelerometer as women } \\
\text { in the control group plus a } \\
\text { mobile phone application, a } \\
\text { daily message, activity di- } \\
\text { ary, and feedback graphs of } \\
\text { personal data (15) }\end{array}$ & $\begin{array}{l}\text { The standard care spiral } \\
\text { notebook replaced with a } \\
\text { mobile app with identical } \\
\text { content. (72) }\end{array}$ & $\begin{array}{l}\text { In addition to standard care, } \\
\text { participants were given a } \\
\text { mobile app to record data, a } \\
\text { proprietary medical device } \\
\text { intended for measuring lung } \\
\text { function (COPD-6) and a } \\
\text { written asthma action plan } \\
\text { (36) }\end{array}$ \\
\hline
\end{tabular}


Table 3. Participant characteristics.

\begin{tabular}{|c|c|c|c|c|}
\hline Study characteristics & Ainscough et al [22] & Choi et al [23] & Ledford et al [24] & Zairina et al [25] \\
\hline Participant risk category & Moderate & Low & Low & Moderate \\
\hline Total number of participants, $N$ & 204 & 30 & 150 & 72 \\
\hline Control, $\mathrm{n}$ & 98 & 15 & 78 & 36 \\
\hline Intervention, $\mathrm{n}$ & 106 & 15 & 72 & 36 \\
\hline Inclusion characteristic among pregnant women & $\begin{array}{l}\text { Body mass index } \geq 25 \\
\text { and }<40 \mathrm{~kg} / \mathrm{m}^{2}\end{array}$ & $\begin{array}{l}\text { Desire to increase } \\
\text { physical activity }\end{array}$ & Low-risk & Asthma \\
\hline Group differences & No & No & No & No \\
\hline Age (years), mean (SD) & $-^{\mathrm{a}}$ & $33.7(2.6)$ & $28.91(5.03)$ & $31.45(4.5)$ \\
\hline Gestation age at recruitment (weeks); mean (SD) & $15^{\mathrm{b}}$ & $17.2(3.4)$ & $10-12^{\mathrm{b}}$ & $16.35(2.9)$ \\
\hline Married $^{\mathrm{c}}, \mathrm{n}(\%)$ & - & $29(97)$ & $133(92.4)$ & $56(78)$ \\
\hline Body mass index $\left(\mathrm{kg} / \mathrm{m}^{2}\right)^{\mathrm{d}}$, mean $(\mathrm{SD})$ & - & $27.7(3.7)$ & - & $28.5(5.7)$ \\
\hline \multicolumn{5}{|l|}{ Race/ethnicity ${ }^{\mathrm{e}} \mathrm{n}(\%)$} \\
\hline White & - & $13(43)$ & $100(69.4)$ & $60(83)$ \\
\hline Asian & - & $12(40)$ & $8(5.6)$ & $6(8)$ \\
\hline Black/African-American & - & $2(7)$ & $14(9.7)$ & - \\
\hline Hispanic/Latina & - & $3(10)$ & $15(10.4)$ & - \\
\hline Other & - & - & $7(4.7)$ & $6(8)$ \\
\hline \multicolumn{5}{|l|}{ Education, $\mathbf{n}(\%)$} \\
\hline High school graduate & - & $6(20)$ & $51(34.0)$ & $9(13)$ \\
\hline University graduate & - & $24(80)$ & $92(61.3)$ & $45(63)$ \\
\hline Ability to communicate in English & - & Yes & - & Yes \\
\hline
\end{tabular}

${ }^{\mathrm{a}}$ Dashes indicate unreported values.

${ }^{\mathrm{b}}$ Standard deviation was not reported.

'Studies reporting data used the term "married," except the Choi et al study, with response category "married/cohabitating."

${ }^{\mathrm{d}}$ Choi et al reported prepregnancy body mass index. Zairina et al reported study baseline.

${ }^{\mathrm{e}}$ Response categories as described by study authors. 
Table 4. Intervention features by the Template for Intervention Description and Replication (TIDieR) checklist.

\begin{tabular}{|c|c|c|c|c|}
\hline Study characteristics & Ainscough et al [22] & Choi et al [23] & Ledford et al [24] & Zairina et al [25] \\
\hline Brief name (trial registration) & $\begin{array}{l}\text { Pears (Pregnancy, exercise, } \\
\text { and nutrition research study } \\
\text { with mobile phone app sup- } \\
\text { port) study (IC- } \\
\text { TRN29316280) }\end{array}$ & $\begin{array}{l}\text { MOTHER (Mobile Technolo- } \\
\text { gies to Help Enhancing } \\
\text { Regular Physical Activity) } \\
\text { Trial for Pregnant Women } \\
\text { (NCT 01461707) }\end{array}$ & $\begin{array}{l}\text { Mobile app as a prenatal ed- } \\
\text { ucation and engagement tool } \\
\text { (No registration provided) }\end{array}$ & $\begin{array}{l}\text { MASTERY (Management } \\
\text { of Asthma with Supportive } \\
\text { Telehealth of Respiratory } \\
\text { function in Pregnancy } \\
\text { Telehealth to improve } \\
\text { asthma control in pregnan- } \\
\text { cy) study (ACTRN } \\
\text { 12613000800729) }\end{array}$ \\
\hline Why & $\begin{array}{l}\text { Investigate the influence of } \\
\text { mobile app-supported ante- } \\
\text { natal healthy lifestyle inter- } \\
\text { vention on the behavioral } \\
\text { stage of change }\end{array}$ & $\begin{array}{l}\text { Examine the feasibility of } \\
\text { an mHealth physical activity } \\
\text { program }\end{array}$ & $\begin{array}{l}\text { Compare the effectiveness } \\
\text { of a mobile app with a spi- } \\
\text { ral-notebook guide in prena- } \\
\text { tal care }\end{array}$ & $\begin{array}{l}\text { Evaluate the efficacy of a } \\
\text { telehealth program support- } \\
\text { ed by a handheld respirato- } \\
\text { ry device in improving } \\
\text { asthma control during } \\
\text { pregnancy }\end{array}$ \\
\hline What (materials) & Mobile app & Mobile app, accelerometer & Mobile app & $\begin{array}{l}\text { Mobile app, a proprietary } \\
\text { medical device intended } \\
\text { for measuring lung func- } \\
\text { tion (COPD-6), individual- } \\
\text { ized written asthma action } \\
\text { plan (WAAP) }\end{array}$ \\
\hline What (procedures) & $\begin{array}{l}\text { Participants received individ- } \\
\text { ualized nutrition counseling } \\
\text { and exercise advice, and } \\
\text { mobile app. Behavioral } \\
\text { stage-of-change score mea- } \\
\text { sured at baseline and late } \\
\text { pregnancy }\end{array}$ & $\begin{array}{l}\text { Participants provided with a } \\
\text { mobile app, accelerometer, } \\
\text { and goal-setting session at } \\
\text { baseline. Data remotely } \\
\text { monitored and extracted }\end{array}$ & $\begin{array}{l}\text { Participants provided with a } \\
\text { mobile app. Paper-based } \\
\text { surveys completed at each } \\
\text { prenatal appointment. App } \\
\text { use assessed. Outcomes re- } \\
\text { ported from health record at } \\
\text { delivery }\end{array}$ & $\begin{array}{l}\text { Participants received a } \\
\text { COPD- } 6 \text {, mobile app, and } \\
\text { individualized WAAP. } \\
\text { Data transmitted automati- } \\
\text { cally to a server accessed } \\
\text { by researchers, partici- } \\
\text { pants, and clinicians. Data } \\
\text { collected at } 3 \text { and } 6 \text { months } \\
\text { from baseline, and after } \\
\text { delivery }\end{array}$ \\
\hline Who provided & Not described & Research staff & $\begin{array}{l}\text { Antenatal care providers, } \\
\text { researchers }\end{array}$ & $\begin{array}{l}\text { Antenatal care providers, } \\
\text { researchers }\end{array}$ \\
\hline How & Mobile app & Mobile app & Mobile app & Mobile app \\
\hline Where & $\begin{array}{l}\text { Not described. Study authors } \\
\text { based in Dublin, Ireland }\end{array}$ & $\begin{array}{l}\text { Not described. Participants } \\
\text { recruited by obstetricians, } \\
\text { prenatal clinics, and commu- } \\
\text { nities (San Francisco, United } \\
\text { States) }\end{array}$ & $\begin{array}{l}\text { Community hospital in } \\
\text { women's health and family } \\
\text { medicine departments } \\
\text { (Maryland, United States) }\end{array}$ & $\begin{array}{l}\text { Antenatal clinics of two } \\
\text { large maternity hospitals } \\
\text { (Melbourne, Australia) }\end{array}$ \\
\hline When and how much & $\begin{array}{l}\text { From (mean of) } 15 \text { weeks' } \\
\text { gestation to } 28 \text { weeks' gesta- } \\
\text { tion }\end{array}$ & $\begin{array}{l}\text { From } 10-20 \text { weeks' gesta- } \\
\text { tion, continuing for } 12 \\
\text { weeks }\end{array}$ & $\begin{array}{l}\text { From } 8-10 \text { weeks' gestation, } \\
\text { continuing throughout preg- } \\
\text { nancy }\end{array}$ & $\begin{array}{l}\text { From (mean of) } 16.7 \\
\text { weeks' gestation, continu- } \\
\text { ing throughout pregnancy }\end{array}$ \\
\hline Tailoring & $\begin{array}{l}\text { Individualized nutrition and } \\
\text { exercise advice }\end{array}$ & $\begin{array}{l}\text { Individualized prescheduled } \\
\text { weekly step goals }\end{array}$ & Not described & $\begin{array}{l}\text { Individualized WAAP and } \\
\text { weekly feedback messages }\end{array}$ \\
\hline $\begin{array}{l}\text { Modification of intervention } \\
\text { during trial }\end{array}$ & Not described & Not described & Not described & Not described \\
\hline $\begin{array}{l}\text { Strategies to improve or } \\
\text { maintain intervention fidelity }\end{array}$ & Not described & $\begin{array}{l}\text { Feedback offered on user } \\
\text { progress, based on uploaded } \\
\text { activity diaries }\end{array}$ & Not described & $\begin{array}{l}\text { Feedback based on individ- } \\
\text { ualized WAAP, lung func- } \\
\text { tion and asthma symptoms }\end{array}$ \\
\hline Extent of intervention fidelity & $\begin{array}{l}\text { Retention and adherence } \\
\text { rates not reported }\end{array}$ & $\begin{array}{l}97 \% \text { (29/30) participants re- } \\
\text { tained during the interven- } \\
\text { tion. Adherence by interven- } \\
\text { tion group waned over the } \\
\text { study period }\end{array}$ & $\begin{array}{l}73 \%(127 / 173) \text { participants } \\
\text { retained during the interven- } \\
\text { tion. Change mainly due to } \\
\text { miscarriage and elevation to } \\
\text { high-risk care }\end{array}$ & $\begin{array}{l}96 \%(69 / 72) \text { participants } \\
\text { retained during the inter- } \\
\text { vention }\end{array}$ \\
\hline
\end{tabular}


Table 5. Primary maternal outcomes: change in maternal behaviors by intervention goals.

\begin{tabular}{|c|c|c|}
\hline \multirow[t]{2}{*}{ Study } & \multicolumn{2}{|l|}{ Study results } \\
\hline & Primary maternal outcome & Results \\
\hline Ainscough et al [22] & $\begin{array}{l}\text { - Shift in the stage-of-change score (transitioning from } \\
\text { contemplation/preparation to maintenance stage of } \\
\text { healthy lifestyle behaviors in pregnancy): baseline to } 28 \\
\text { weeks. } \\
\text { - Study participants at Maintenance stage (stage 5). }\end{array}$ & $\begin{array}{l}\text { - Mean score showing a shift in stage-of-change score } \\
\text { distribution observed for both groups. Change reported } \\
\text { as more significant for the intervention group }(P<.001 \\
\text { versus } P=.03) \text {. The proportion in each group achieving } \\
\text { change not reported. } \\
\text { At } 28 \text { weeks, a higher proportion of intervention group } \\
\text { at stage } 5(52.8 \%) \text { compared with the control group } \\
(32.7 \%),\left(\chi^{2}=8.4, P=.004\right) \text {. }\end{array}$ \\
\hline
\end{tabular}

Choi et al [23]

- Physical activity: change in mean steps per day.
- Intervention participants had a greater increase in daily steps at 12 weeks with 1096 (SD 1898) steps, compared with 259 (SD 1604) steps among control participants $(P=.13)$.

Ledford et al [24]

- $\quad$ Patient use of a tool to find information about pregnancy (information-seeking).

- Patient use of tool to record information about pregnancy (information-recording).

- Patient activation at 32 weeks' gestation (use of a tool).

- No significant difference detected between the 2 groups (data not provided).

- Across all time points, intervention group recorded more frequent use of information source than the control group $\left(F[1118]=4.10, P \geq .05,{ }^{2}=.03\right)$.

- The intervention group activation score was greater than controls (patient activation score marginal mean 79.88 versus $74.81\left(F[1127]=4.99, P \geq .05,{ }^{2}=.04\right)$.

- Mean difference between groups was significant $(-0.36$ [SD 0.15], $P=.02$ ). The intervention group had higher proportion of participants with well-controlled asthma than the control group ( $82 \%$ versus $58 \%, P=.03$ ).

\section{Secondary Outcomes}

Of the 4 studies in this review, 2 studies [23,25] report maternal secondary outcomes relevant to this review, as further detailed in Multimedia Appendix 6. One study of asthma control reports a clinically significant improvement in the asthma-related quality of life among the intervention group compared with usual care at 6 months from baseline, but the mean change was not statistically significant [25]. Another study of physical activity during pregnancy reported reduced barriers such as lack of energy, time, and willpower among the intervention group, and decreased severity of pregnancy symptoms [23]. No studies reported data on major adverse maternal outcome, maternal knowledge about the targeted health topic, maternal evaluation of the intervention, or successful initiation of breastfeeding. Furthermore, none of the trials report statistically significant differences in neonatal outcomes between intervention and control groups.

\section{Discussion}

\section{Principal Findings}

Despite the broad search criteria used, this systematic review identified only 4 studies for inclusion. This was an unexpected outcome of the review given the expanding use of mobile applications in maternity care. All studies included in the review reported on the primary outcome, "change in maternal behaviors by intervention goals," but the specific outcomes reported varied by intervention. None of the studies included in this review reported statistically significant differences between intervention and control groups for neonatal outcomes, delivery or pregnancy complications. As advocated through the Core Outcomes in Women's and Newborn Health initiative, a standard set of perinatal outcome measures, reported alongside those appropriate to specific health conditions or interventions, would enhance comparability [26-27]. A standardized approach using reliable and valid methods to analyze participant usage, navigation, adherence, and satisfaction would also improve comparability further and inform the design of future interventions.

Further areas for research include investigation of which intervention features yield the desired results, for example, to establish if it is an individualised clinical care plan or the advice supported by a mobile app that makes a difference. Future studies could also explore how technology can support individualized patient care plans, and if technology can be used for data tracking or streamlined reporting of symptoms to automatically prompt closer clinical scrutiny. A more in-depth exploration of the theories of behavior change underpinning study results could also add an important dimension to understand how mobile interventions influence behavior and improved perinatal outcomes.

None of the studies were designed to gauge the longitudinal benefit of mobile app interventions commenced during the perinatal period. This would be another important avenue to understand longer-term benefits, potential diminishing effects, data tracking and patient engagement opportunities offered by interventions commenced during pregnancy. Qualitative research or follow-up surveys of interventions could provide insight into 
users' experiences of these interventions, including how such apps are used, and if they augment or affect perceptions of care.

Hundreds of pregnancy apps are available to the public, yet all the studies in this review developed their own mobile apps. Researchers may find it easier to guide content, facilitate communication, track data and assure user privacy with their own apps. The potential commercialization of successful interventions that could generate income for research programs could also be a consideration. However, bespoke models are likely to require more investment in development, testing, maintenance, and marketing than existing apps.

Despite creating their own apps, reviewed studies did not report extensively on their development, testing or architecture, or whether modifications were required, which would assist replication efforts. Further, none of the included studies reported an economic analysis, comparing the cost of the intervention with standard care or comparators. Policymakers and those guiding educational or clinical interventions during pregnancy would likely require such information to gauge investment alongside projected perinatal health benefits.

\section{Strengths and Limitations}

There are several important strengths and limitations in our review. To the best of our knowledge, this systematic review is the first to assess the effects of mobile app interventions during pregnancy on influencing healthy maternal behavior and improving perinatal outcomes. This review followed an established methodology for the conduct of systematic reviews $[17,19]$ and used a highly sensitive search strategy with no language or date restrictions to identify as many relevant studies as possible. Two authors completed the review process and extracted data independently at all stages based on prespecified criteria, and a third author participated when required to achieve consensus. Included studies were limited to those which provided comparators between mobile applications and any other intervention, including standard care, so that the role of the communication modality on intervention effects could be analyzed.

This review may have some methodological limitations. Findings are limited by the few studies that met inclusion criteria, and the small sample sizes involved in each study. Although search criteria and the databases searched were comprehensive, it is possible that relevant articles were missed. Only articles published in peer-reviewed journals were included, which may have left out some studies. Over 3,000 published study abstracts were assessed, and it was unexpected that only 4 studies would meet inclusion criteria. The heterogeneity of outcome measures further hampered the ability to meta-analyse data as originally intended, or to explore impact. Future updates of this review could search additional databases and expand the inclusion criteria to enable the analyses originally intended by the authors.

\section{Conclusions}

As an increasing number of pregnant women use mobile apps, further research on intervention components, usage, and associated perinatal health outcomes should influence content, features, and quality of interventions. The effect of mobile app interventions on maternal knowledge, behaviour, and perinatal outcomes is still largely underreported, as evidenced by the few studies that met inclusion criteria for this review, and the minimal significant impact reported on perinatal health outcomes. Results of this systematic review may contribute to decision making by health systems, hospitals, and clinicians about the integration of mobile applications into clinical care. Emerging evidence from future trials should help to make firmer conclusions about the effectiveness of mobile app interventions during pregnancy on primary and secondary outcomes, compared to other communication modes.

\section{Acknowledgments}

The research reported in this publication is part of the Centre of Research Excellence in Stillbirth (Stillbirth CRE). Core funding to support the Stillbirth CRE is provided by the National Health and Medical Research Council (NHMRC). This systematic review is part of the corresponding author's doctoral thesis, which is funded through an Australian Government Research Training Program (RTP) scholarship facilitated through The University of Queensland, a Frank Clair Scholarship from Mater Research Institute, and a Top-up Scholarship from the Stillbirth CRE. The following institutions have provided support to review authors to allow them to undertake this review: (1) Mater Research Institute, The University of Queensland, Australia, (2) South Australian Health and Medical Research Institute (SAHMRI), Adelaide, Australia, and (3) School of Psychology and Public Health, La Trobe University, Australia. Supporting institutions are not involved in aspects of the project such as the design of the protocol, and analysis plan, data collection and analyses, data interpretation or publication of study results.

\section{Conflicts of Interest}

None declared

\section{Authors' Contributions}

LMD and VF conceptualized the review in consultation with the coreviewers. LMD performed the literature search with a clinical librarian. All authors (LMD, FMB, DH, PFM, VF) screened studies to determine inclusion. LMD and VF performed data collection, data extraction, and bias assessment. LMD wrote the manuscript, with review and input from all authors. The corresponding author is the guarantor of this review. 


\section{Multimedia Appendix 1}

Search terms and returns.

[PDF File (Adobe PDF File), 89KB-Multimedia Appendix 1]

\section{Multimedia Appendix 2}

Excluded studies.

[PDF File (Adobe PDF File), 61KB-Multimedia Appendix 2]

\section{Multimedia Appendix 3}

Bias assessment.

[PDF File (Adobe PDF File), 103KB-Multimedia Appendix 3]

\section{Multimedia Appendix 4}

Intervention characteristics.

[PDF File (Adobe PDF File), 79KB-Multimedia Appendix 4]

\section{Multimedia Appendix 5}

Inventories used in included studies.

[PDF File (Adobe PDF File), 92KB-Multimedia Appendix 5]

\section{Multimedia Appendix 6}

Secondary outcomes.

[PDF File (Adobe PDF File), 181KB-Multimedia Appendix 6]

\section{References}

1. Lawn JE, Blencowe H, Waiswa P, Amouzou A, Mathers C, Hogan D, et al with the Lancet Ending Preventable Stillbirths Series study group and the Lancet Stillbirth Epidemiology investigator group. Stillbirths: rates, risk factors, and acceleration towards 2030. Lancet 2016 Feb 06;387(10018):587-603. [doi: 10.1016/S0140-6736(15)00837-5] [Medline: 26794078]

2. Aune D, Saugstad OD, Henriksen T, Tonstad S. Maternal body mass index and the risk of fetal death, stillbirth, and infant death: a systematic review and meta-analysis. JAMA 2014 Apr 16;311(15):1536-1546. [doi: 10.1001/jama.2014.2269] [Medline: 24737366]

3. Marufu TC, Ahankari A, Coleman T, Lewis S. Maternal smoking and the risk of still birth: systematic review and meta-analysis. BMC Public Health 2015 Mar 13;15:239 [FREE Full text] [doi: 10.1186/s12889-015-1552-5] [Medline: 25885887]

4. Flenady V, Middleton P, Smith GC, Duke W, Erwich JJ, Khong TY, et al for the Lancet's Stillbirths Series steering committee. Stillbirths: the way forward in high-income countries. Lancet 2011 May 14;377(9778):1703-1717. [doi: 10.1016/S0140-6736(11)60064-0] [Medline: 21496907]

5. Deave T, Johnson D, Ingram J. Transition to parenthood: the needs of parents in pregnancy and early parenthood. BMC Pregnancy Childbirth 2008 Jul 29;8:30 [FREE Full text] [doi: 10.1186/1471-2393-8-30] [Medline: 18664251]

6. Lupton D, Pedersen S. An Australian survey of women's use of pregnancy and parenting apps. Women Birth 2016 Aug;29(4):368-375. [doi: 10.1016/j.wombi.2016.01.008] [Medline: 26874938]

7. O'Higgins A, Murphy OC, Egan A, Mullaney L, Sheehan S, Turner MJ. The use of digital media by women using the maternity services in a developed country. Ir Med J 2014;107(10):313-315. [Medline: 25556255]

8. Lupton D. The use and value of digital media for information about pregnancy and early motherhood: a focus group study. BMC Pregnancy Childbirth 2016 Jul 19;16(1):171 [FREE Full text] [doi: 10.1186/s12884-016-0971-3] [Medline: 27435182]

9. Hearn L, Miller M, Fletcher A. Online healthy lifestyle support in the perinatal period: what do women want and do they use it? Aust J Prim Health 2013;19(4):313-318. [doi: 10.1071/PY13039] [Medline: 23899373]

10. Wellde PT, Miller LA. There's an App for That!: New Directions Using Social Media in Patient Education and Support. J Perinat Neonatal Nurs 2016;30(3):198-203. [doi: 10.1097/JPN.0000000000000177] [Medline: 27465449]

11. Daly LM. Apps and opps: mobile applications and opportunities for longitudinal data collection across the reproductive lifespan. In: ALSWH Scientific Meeting 2016 - Abstracts. 2016 Presented at: Australian Longitudinal Study of Women's 
Health Scientific Meeting; 4-5 May 2016; Newcastle URL: https://www.alswh.org.au/images/content/scientificmeeting/ ALSWH Scientific Meeting Abstracts.pdf

12. research2guidance. mHealth App Economics 2017: Current Status and Future Trends in Mobile Health. Berlin, Germany: research2guidance; 2017:1-25.

13. Thomas GM, Lupton D. Threats and thrills: pregnancy apps, risk and consumption. Health, Risk \& Society 2015 Dec 24;17(7-8):495-509. [doi: 10.1080/13698575.2015.1127333]

14. Agarwal S, Labrique A. Newborn health on the line: the potential mHealth applications. JAMA 2014 Jul 16;312(3):229-230. [doi: 10.1001/jama.2014.6371] [Medline: 24953141]

15. Gates S. Cochrane Pregnancy and Childbirth Group Methodological Guidelines. Cochrane Pregnancy and Childbirth Group, Cochrane Collaboration; 2012. URL: http://pregnancy.cochrane.org/sites/pregnancy.cochrane.org/files/public/uploads/ MethodologicalGuidelines\%20\%28July\%202012\%29 0.pdf[WebCite Cache ID 6yuLD6jy6]

16. Veritas Health Innovation. Covidence systematic review software. Melbourne, Australia; 2016. URL: https://www. covidence.org/home [accessed 2018-07-24] [WebCite Cache ID 71AFb8I9n]

17. Higgins JPT, Green S. Cochrane Handbook for Systematic Reviews of Interventions Version 5.1.0. The Cochrane Collaboration; 2011. URL: http://training.cochrane.org/handbook[WebCite Cache ID 6wLih6wy5]

18. Hoffmann TC, Glasziou PP, Boutron I, Milne R, Perera R, Moher D, et al. Better reporting of interventions: template for intervention description and replication (TIDieR) checklist and guide. BMJ 2014;348:g1687 [FREE Full text] [Medline: 24609605]

19. Hoffmann TC, Oxman AD, Ioannidis JP, Moher D, Lasserson TJ, Tovey DI, et al. Enhancing the usability of systematic reviews by improving the consideration and description of interventions. BMJ 2017 Dec 20;358:j2998. [Medline: 28729459]

20. Daly LM, Horey D, Middleton PF, Boyle FM, Flenady V. The effect of mobile application interventions on influencing healthy maternal behaviour and improving perinatal health outcomes: a systematic review protocol. Syst Rev 2017 Feb 08;6(1):26 [FREE Full text] [doi: 10.1186/s13643-017-0424-8] [Medline: 28179012]

21. Moher D, Liberati A, Tetzlaff J, Altman DG. Preferred reporting items for systematic reviews and meta-analyses: the PRISMA statement. PLoS Med 2009 Jul 21;6(7):e1000097 [FREE Full text] [doi: 10.1371/journal.pmed.1000097] [Medline: 19621072]

22. Ainscough K, Kennelly M, Lindsay K, O'Sullivan E, McAuliffe F. Impact of an mHealth supported healthy lifestyle intervention on behavioural stage of change in overweight and obese pregnancy. Proc. Nutr. Soc 2016 Nov 24;75(OCE3). [doi: 10.1017/S0029665116001002]

23. Choi J, Lee JH, Vittinghoff E, Fukuoka Y. mHealth Physical Activity Intervention: A Randomized Pilot Study in Physically Inactive Pregnant Women. Matern Child Health J 2016 May;20(5):1091-1101. [doi: 10.1007/s 10995-015-1895-7] [Medline: 26649879]

24. Ledford CJW, Canzona MR, Cafferty LA, Hodge JA. Mobile application as a prenatal education and engagement tool: A randomized controlled pilot. Patient Educ Couns 2016 Apr;99(4):578-582. [doi: 10.1016/j.pec.2015.11.006] [Medline: 26610389]

25. Zairina E, Abramson MJ, McDonald CF, Li J, Dharmasiri T, Stewart K, et al. Telehealth to improve asthma control in pregnancy: A randomized controlled trial. Respirology 2016 Jul;21(5):867-874. [doi: 10.1111/resp.12773] [Medline: 27037722]

26. van 't Hooft J, Alfirevic Z, Asztalos EV, Biggio JR, Dugoff L, Hoffman M, et al. CROWN initiative and preterm birth prevention: researchers and editors commit to implement core outcome sets. BJOG 2018 Jan;125(1):8-11. [doi:

10.1111/1471-0528.14987] [Medline: 29055092]

27. Khan K on behalf of Chief Editors of Journals participating in The CROWN Initiative (Appendix 1). The CROWN Initiative: journal editors invite researchers to develop core outcomes in women's health. BJOG 2016 Sep;123 Suppl 3:103-104 [FREE Full text] [doi: 10.1111/1471-0528.14363] [Medline: 27627608]

\author{
Abbreviations \\ COPD-6: a proprietary medical device intended for measuring lung function \\ RCT: randomized controlled trial \\ SMS: short message service \\ TIDieR: Template for Intervention Description and Replication \\ WAAP: written asthma action plan
}


Edited by G Eysenbach; submitted 01.02.18; peer-reviewed by F Drozd, I Peterson; comments to author 19.03.18; revised version received 29.05.18; accepted 18.06.18; published 09.08.18

Please cite as:

Daly LM, Horey D, Middleton PF, Boyle FM, Flenady V

The Effect of Mobile App Interventions on Influencing Healthy Maternal Behavior and Improving Perinatal Health Outcomes: Systematic Review

JMIR Mhealth Uhealth 2018;6(8):e10012

URL: http://mhealth.jmir.org/2018/8/e10012/

doi: $\underline{10.2196 / 10012}$

PMID: $\underline{30093368}$

CLisa M Daly, Dell Horey, Philippa F Middleton, Frances M Boyle, Vicki Flenady. Originally published in JMIR Mhealth and Uhealth (http://mhealth.jmir.org), 09.08.2018. This is an open-access article distributed under the terms of the Creative Commons Attribution License (https://creativecommons.org/licenses/by/4.0/), which permits unrestricted use, distribution, and reproduction in any medium, provided the original work, first published in JMIR mhealth and uhealth, is properly cited. The complete bibliographic information, a link to the original publication on http://mhealth.jmir.org/, as well as this copyright and license information must be included. 